\begin{tabular}{|l|l|} 
DOI 10.31558/2307-2318.2020.4.25 & \\
УДК 338.04 & JEL: M21, I23
\end{tabular}

\author{
Юрчишена Л.В., \\ кандидат економічних наук, доцент, \\ доцент кафедри фінансів і банківської справи \\ Донецького національного університету імені Василя Стуса \\ ORCID: 0000-0002-5904-0758 \\ l.yurchishena@donnu.edu.ua
}

\title{
ВИЗНАЧЕННЯ БІЗНЕС-МОДЕЛІ УНІВЕРСИТЕТУ НА ОСНОВІ СИНТЕЗУ ПІДХОДІВ ДО БІЗНЕС-МОДЕЛІ ПІДПРИСМСТВА
}

У статті досліджено та структуровано генезис підходів вітчизняних та іноземних вчених до поняття «бізнес-модель», в результаті виокремлено стратегічний, клієнтоорієнтований, ціннісний, процесний, системний підхід, а також підходи, що ототожнюють бізнес-модель як інструмент управління, механізм, визначають іiі як когнітивну систему. Досліджено підходи вчених до наповненості бізнес-моделі компонентами, що доводить іï унікальність та можливість використання в різних галузях.

Визначено, що при розробці бізнес-моделі університету доцільно дотримуватися комплексного підходу, що поєднує стратегічний, ціннісний, клієнтоорієнтований, процесний i системний підходи. Наведено розуміння поняття бізнес-модель університету як концептуального інструменту, який базується на стратегічному баченні розвитку закладу вищої освіти, включає взаємопов'язаний набір компонентів створення ціннісної пропозиції для стейкголдерів та здатності університету генерувати доходи задля забезпечення фінансової стійкості. Здійснено змістовне наповнення складових бізнес-моделі Остервальдера А., Піньє І. для вітчизняних університетів.

Ключові слова: бізнес-модель, бізнес-модель університету, ціннісна пропозиція, компоненти бізнес-моделі, канва бізнес-моделі.

Рис. -5 , Табл. -1 , Літ. -26

Постановка проблеми. Сучасні дослідження в різних галузях знань все більше уваги приділяють вивченню теоретичних і практичних аспектів бізнес-моделі, що пов'язано $з$ посиленням інтересу i потребую бізнесу до науково обгрунтованого розуміння діяльності підприємств. Різноманітність напрямків досліджень $\epsilon$ передумовою різнобічного трактування поняття «бізнес-модель», iii наповнення певними компонентами та цільового призначення. Розвиток даного поняття і зміна підходів до управління вітчизняними університетами зумовлюють дослідження можливостей використання бізнес-моделей в їх діяльності, адже в рамках розширення автономії закладів вищої освіти доцільно впроваджувати нові підходи до управління і ведення освітньо-наукової діяльності, що може формуватися на стику бізнесу та освіти.

Аналіз останніх досліджень і публікацій. Дослідження генезису поняття «бізнес-модель» набуло значної популярності серед вітчизняних та іноземних науковців. Проте, позиції вчених є досить неоднозначними та дискусійними, так N. Foss, T. Saebi, I. Чухрай досліджують бізнес-модель як інструмент управління, 
стратегічні аспекти відображені в працях R. Casadesus-Masanell, J. Ricart, P. Keen, S. Qureshi, M. Levy, G. Hamel, Д. Кліманова, О. Третьяк, клієнтоорієнтований підхід прослідковується в працях А. Сливотскі, C. Zott, процесний підхід до визначення поняття «бізнес-модель» застосовує A. Afuah, G. Pohle, M. Chapman, C. Zott, R. Amit, Д. Кліманов, О. Третьяк, ціннісного підходу дотримуються Н. Кузьмина, на думку, I. Нєнно, В. Скриль, бізнес-модель є механізмом, про унікальності бізнес-моделі наголошує в своїх працях $\mathrm{H}$. Chesbrough, бізнес-модель як систему досліджує $\mathrm{H}$. Стрекалова, бізнес-модель як когнітивна система досліджується в працях Е. Жайлауов, Е. Белик, И. Денисов. Проте, попри велику кількість досліджень і теоретичного підгрунтя до поняття «бізнес-модель» в різних галузях знань, вирішення даної проблеми потребує подальшого розвитку і можливості застосування бізнес-моделей в університетах.

Метою статті $\epsilon$ формування сутності та бачення «бізнес-моделі університету»на основі дослідження та структурування існуючих підходів до поняття «бізнес-модель» в різних галузях знань, виокремлення іiї компонентів та взаємозв'язків між ними.

Виклад основного матеріалу. Сучасні дослідження у сфері соціальноекономічних, поведінкових та управлінських наук все більше уваги приділяють бізнесмоделям, підходи до трактування яких є досить різноманітними, що різняться не лише складністю представлення, але й змістовним наповненням, науковці досліджують бізнес-модель як абстрактне поняття, як концепцію бізнесу, можливість змоделювати і вирішити реальні ситуації, проблеми. Тому, для науково обгрунтованого розуміння поняття «бізнес-модель» доцільно дослідити існуючі наукові доробки в даному напрямку, здійснити аналіз дефініцій поняття «бізнес-модель», і виділити підходи до їі сутності (рис. 1).

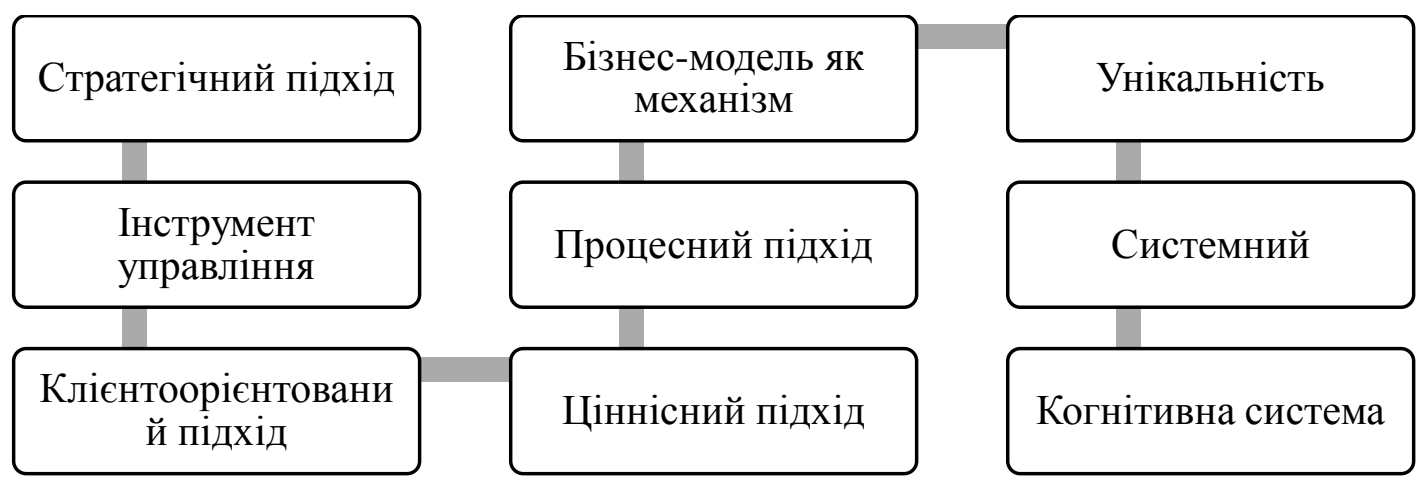

Рисунок 1. Підходи до поняття «бізнес-модель»

*складено автором на основі дослідження підходів до поняття «бізнес-модель»

Бізнес-модель призначена для опису основних принципів створення, розвитку i успішної роботи організації. Бізнес-модель - це те, що відрізняє об'єкт дослідження від інших, це певна унікальність, виражена через взаємозв'язки між критичними факторами успіху. Бізнес-модель важливіша місії, стратегії і плану грошових потоків, це конкурентна перевага підприємства [1, с. 5]. Наявність бізнес-моделі на підприємстві дає можливість зрозуміти, що і як потрібно робити, щоб досягти бажаного результату [2, с. 491].

Для кожної організації створюється своя унікальна, досконала модель ведення бізнесу, яка спрямована на отримання економічного результату різними інструментами.

Бізнес-модель як інструмент управління пояснює яким чином і для кого бізнес створює цінність, як ії розподіляє і привласнює [3]. Чухрай І.А. дослідивши онтологію 
понять «бізнес-модель», трактує іï як управлінську концепцію щодо того, як саме на основі існуючих ключових компетенцій та вибраного стратегічного набору задля досягнення поставлених цілей створити цінність для клієнтів та примножити вартість підприємства [4, с. 97]. Перевагами запропонованого підходу є поєднання вартісного і ціннісного підходу, що в ринкових умовах призводить до підвищення конкурентоспроможності та задоволення інтересів стейкхолдерів.

Стратегічний підхід до формування бізнес-моделей набуває все більшого розвитку, Casadesus-Masanell R., Ricart J.E. [5] стверджують, що підприємства конкурують унікальними бізнес-моделями, розділяючи концепцію створення стратегії та бізнес-моделі, бізнес-модель формує розуміння логіки створення вартості і цінності для стейкголдерів, стратегія передбачає вибір бізнес-моделі для створення конкурентних переваг на ринку, тактика обирається залежно від цілей підприємства та обраної бізнес-моделі з унікальною конструкцією складових. Подібний підхід прослідковується в дослідженнях Keen P., Qureshi S. [6], які стверджують, що стратегія i бізнес-модель взаємопов'язані, адже стратегія формує бачення компанії в майбутньому, а бізнес-модель $\epsilon$ тактичним, концептуальним та гнучким інструментом, який візуалізує процеси, їх дію на кінцевий результат. Взаємозв'язок бізнес-моделі і стратегії ілюструє «рівняння цінності» M. Levy, визначаючи, що створення цінності для клієнта можливо за рахунок поєднання бізнес-моделі і стратегії підприємства:

$$
\mathrm{V}=\mathrm{M} \times \mathrm{S}
$$

де V - Value (цінність), M - Model (бізнес-модель), S - Strategy (стратегія).

Розвиваючи стратегічний підхід до бізнес-моделі, Hamel G. [7] виділяє чотири складові бізнес-моделі: основна стратегія, стратегічні ресурси компанії, профіль клієнта, ланцюжок створення цінності.

Дослідження зі стратегічного менеджменту щодо формування бізнес-моделі різняться підходами, одні науковці ототожнюють бізнес-модель із стратегією підприємства, порівнюючи інструменти бізнес-моделі із стратегічним набором певних стратегій, інші виділяють як складову стратегії. Стратегія має довгостроковий характер, i містить загальний план досягнення бажаної мети в майбутньому, бізнес-модель показує конкретні інструменти, бізнес-процеси, які дають можливість досягти конкретних цілей. Узагальнення підходів до співвідношення бізнес-моделі і стратегії підприємства представлені в дослідженнях Кліманова Д. Е., Третьяк О. А. [14, с. 114], що розділяють iї на три групи (рис. 2): бізнес-модель як складова стратегії підприємства, стратегія як складова бізнес-моделі, стратегія і бізнес-модель як незалежні складові, які мають властиві їм характеристики.

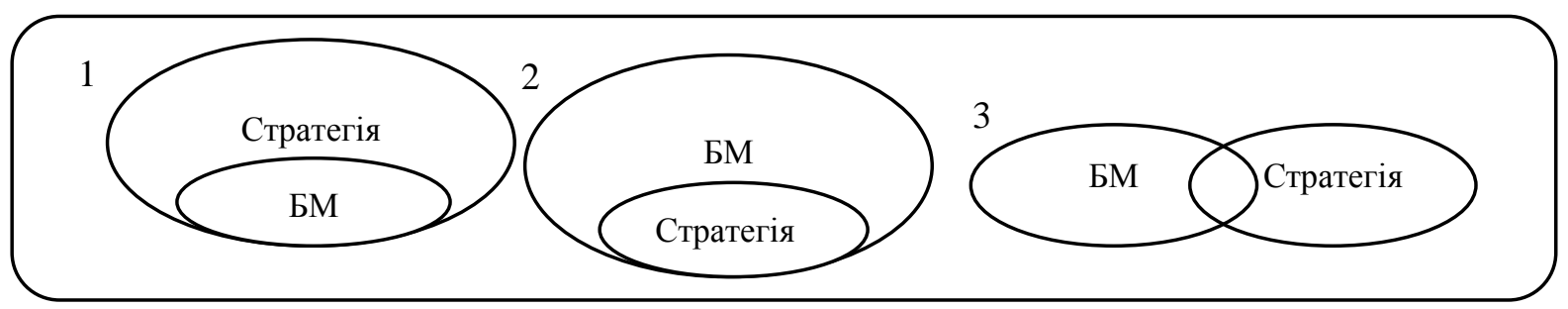

Рисунок 2. Співвідношення стратегії та бізнес-моделі підприємства [16, с. 114]

Клієнтоорієнтований підхід є одним із найбільш поширених до побудови бізнесмоделі, адже орієнтація на клієнта 3 його потребами, задоволення клієнта від його очікувань, це бізнес-моделі націлені на довгострокові взаємовідносини з клієнтами, які 
супроводжуватимуться економічними результатами (стабільними грошовими потоками, прибутком). Клієнтоорієнтований підхід в своїх дослідженнях застосовує Сливотскі А., визначаючи, що бізнес-модель - це те, як компанія вибирає споживача, формує i розмежовує пропозиції, розподіляє ресурси, визначає, які задачі може виконати власними силами, а для яких потрібно залучити сторонні організації, виходить на ринок, створює цінності для споживача і отримує від цього прибуток [8]. Zott C. стверджує, що модель бізнесу - це те, як підприємство вибирає споживача, формує і розмежовує свої пропозиції, розподіляє ресурси, визначає, які завдання зможе виконати своїми силами і для яких доведеться залучати спеціалістів зі сторони, виходить на ринок, створює цінність для споживача і отримує прибуток [9].

Досліджуючи дефініції поняття «бізнес-модель» Сачинська Л.В. [10, с. 173], Скриль В.В. [2, с. 491] виділять два підходи: 1) вартісний, орієнтований на бізнеспроцеси, які відбуваються всередині підприємства 3 метою генерування доходу, прибутку; 2) орієнтований на цінність, що створюється для клієнта.

Процесний niдxid до поняття «бізнес-модель» визначає іiі як сукупність ієрархічних, взаємозалежних процесів. Afuah А. досліджує бізнес-модель як структуру бізнес-процесів і зв'язків між ними, які використовуються для планування, контролю і корекції діяльності підприємства, зазначаючи, що бізнес-модель пояснює, як компанія заробляс гроші, визначаючи їі місце в ланцюжку створення вартості [11]. На думку G. Pohle, M. Chapman бізнес-модель - це метод ведення справ, який базується на створенні споживчої вартості, внаслідок чого компанія заробляє гроші і генерує прибуток [12]. В дослідженнях Zott C., Amit R. [9] вивчають бізнес-модель як сукупність способів та правил ведення бізнесу в компанії (структура, продукція, способи доставки та обслуговування товарів, підвищення ринкової вартості), що лежать в основі стратегії. Бізнес-модель - це спосіб, яким компанія створює цінність для клієнтів і одержує від цього прибуток [9]. Процесного підходу дотримується в своїх дослідженнях Кузьмина Н.В. стверджуючи, що системна сутність бізнес-моделі підприємства передбачає іiі сприйняття як упорядкованої сукупності взаємопов'язаних елементів і відносин між ними, наявних зв'язків підприємства 3 ключовими стейкхолдерами, зовнішнім середовищем, враховує конкурентну стратегію, інноваційну складову створення вартості, є гнучкою та адаптованою до бізнес-середовища [13, с.398]. Кліманов Д. Е., Третьяк О. А. визначають бізнес-модель як процес створення пропозиції цінності для клієнта, в якому беруть участь ряд компаній, які взаємодіють на ринку. При цьому, даний процес $\epsilon$ джерелом доходів для всіх включених в нього агентів, демонструє деяку архітектуру взаємодії компаній на ринку [14, с. 113].

Відповідно до изіннісного підходу бізнес-модель описує цінність, яку підприємство пропонує клієнтам, відображає його здатність здійснювати діяльність, оцінювати пріоритети клієнтів, необхідні для створення, просування і постачання ціннісної пропозиції клієнтам, відносини капіталу, необхідні для отримання стійких доходів [15]. Кузьмін Н.В. досліджує бізнес-моделі в динамічному зовнішньому середовищі, i визначає, як бізнес позиціонує себе в ланцюжку створення цінності в рамках галузі, i як має себе забезпечити, створюючи відповідні умови для отримання економічного результату - прибутку [14, с.397].

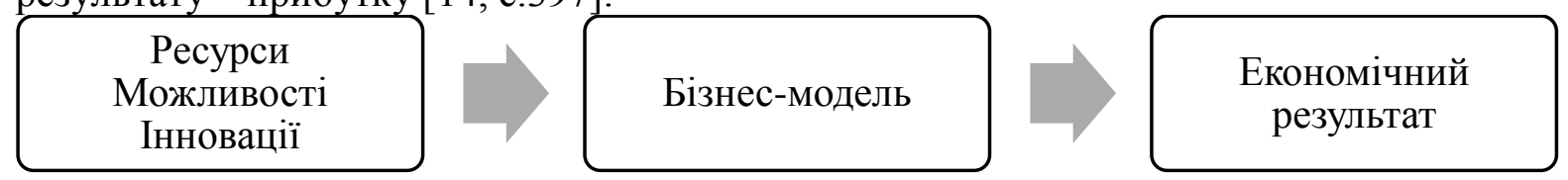

Рисунок 3. Бізнес-модель спрямована на формування економічного результату [14, c.397] 
Наведена схема бізнес-моделі є спрощеною і потребує змістовного наповнення 3 позиції концептуального інструменту дослідження логіки бізнесу, особливостей організації, структурних елементів, взаємозв'язків тощо. Не існує універсальної бізнесмоделі для всіх сфер бізнесу, $\epsilon$ модель, яка включає систему елементів 3 емерджентними характеристиками i системною цілісністю, змістовність яких наповнюється індивідуально необхідними для досягнення економічного результату бізнесу.

Бізнес-модель як механізм створення та зберігання доданої вартості підприємства досліджує професорка Нєнно I. М., яка зазначає, що при такому підході прийняття стратегічних рішень здійснюється за наступними напрямками: вибір сегменту споживачів; формування цінової пропозиції; вибір каналів розповсюдження продукції; стосунки зі споживачами; генерація потоків доходів; ключові ресурси; ключова діяльність; ключові партнерства відповідно до структури EQA (European QualityAward) - Європейської моделі ділової досконалості [16, с. 139]. Такого ж підходу до поняття «бізнес-модель» дотримується Скриль В. В. визначаючи іiі як спрощене відображення механізму ведення економічної діяльності, пов'язаної із виробництвом продукції (товарів, робіт, послуг), що є ціннісною пропозицією для споживача, і забезпечує отримання прибутку [2, с. 491].

Унікальність, як один із підходів до поняття бізнес-модель підприємства - це відображення реально існуючого або запланованого в майбутньому бізнесу в такій формі, яка може наочно демонструвати всі значимі властивості і особливості підприємства, пов'язані 3 його здатністю отримувати прибуток i бути конкурентоспроможним [17].

Системного підходу до поняття «бізнес-модель» дотримується в дослідженнях Стрекалова Н.Д., визначаючи бізнес-модель, як набір пов'язаних модельних елементів, що визначають внутрішнє і зовнішнє середовище компанії в рамках єдиної системи [18]. Системний підхід базується на аналізі структури компонентів бізнес-моделі та їх взаємозв'язків.

Бізнес-модель як когнітивну систему досліджують Жайлауов Е.Б., Белик Е.Б., Денисов И.В. (2019) [19], і зазначають, що створення бізнес-моделі на власних когнітивних функціях (пізнання, сприйняття, уявлення) ТОР-менеджерів, що приймають стратегічні рішення, не є ефективним, так як не передбачає використання науково-обгрунтованих підходів, єдиного бачення побудови бізнес-моделі. Проте, такий підхід формує стратегічне бачення розвитку компанії, і тактичне ведення бізнесу, сприяє структуруванню взаємозв'язків із стейкголдерами, що є основою для прийняття управлінських рішень, формуючи модель бачення компанії, і в більшості випадків немає матеріального відображення.

Аналіз підходів і дефініцій поняття «бізнес-модель» є підгрунтям до визначення «бізнес-модель університету» як концептуального інструменту, який базується на стратегічному баченні розвитку закладу вищої освіти, включає взаємопов'язаний набір компонентів створення ціннісної пропозиції - нових знань для стейкголдерів, здатності університету до монетизації такої спроможності шляхом генерування доходів задля забезпечення фінансової стійкості. Адже саме модель являє собою спрощене відображення складного об'єкта, процесу, що включає найбільш суттєві характеристики.

Запропонований підхід до поняття «бізнес-модель університету» має дати відповідь на три основних питання: 1.Чому клієнти (абітурієнти, бізнес, влада, партнери) налаштовані на споживання та придбання ціннісних інноваційних освітніх та 
наукових продуктів університету? 2. Яким чином університет здатний генерувати доходи пропонуючи ціннісні пропозиції? 3. Які ключові дії повинен виконувати університет задля забезпечення фінансової стійкості?

Узагальнюючи вище зазначене, можна стверджувати, що поняття «бізнес-модель університету» базується на гнучкому поєднанні стратегічного, ціннісного, клієнтоорієнтованого, процесного і системного підходу. Бізнес-модель університету $є$ тактичним інструментом реалізації стратегії, що формує унікальні бізнес-процеси притаманні конкретному закладу вищої освіти з наявною організаційною структурою та ресурсним забезпеченням, функціонує як єдина система задля створення i просування ціннісних пропозицій (value proposition) стейкголдерам, здатна генерувати грошові потоки, величина та синхронність яких залежить від унікальності ціннісної пропозиції, витратомісткості, престижності, масовості, унікальності тощо.

Результати дослідження підходів до поняття «бізнес-модель» дає можливість виокремити iï основні риси: комплексність, адаптивність, гнучкість, динамічність, унікальність, схематичність, структурованість, пратикоорієнтованість.

В науковій літературі підходи до компонентів бізнес-моделі різняться за своїм складом і змістовним наповненням (табл. 1.1), що обумовлено розумінням даного поняття. Виокремлення компонентів бізнес-моделі, їх взаємозв'язків із зовнішнім та внутрішнім середовищем.

Таблиця 1

Підходи до визначення компонентів бізнес-моделі

\begin{tabular}{|c|c|}
\hline Автор & Компоненти бізнес-моделі \\
\hline Чухрай I.A. [21] & $\begin{array}{l}\text { 1) ціннісна пропозиція; } \\
\text { 2) ключові ресурси (люди, технології, товари, обладнання, інформація, партнерство, } \\
\text { альянси, бренд); } \\
\text { 3) формула прибутку (модель доходу, структуру витрат, модель рентабельності, } \\
\text { оборотність ресурсів); } \\
\text { 4) ключові процеси, правила, показники, норми. }\end{array}$ \\
\hline $\begin{array}{l}\text { Джонсонс М., } \\
\text { Крістенсен К., } \\
\text { Кагерманн X. } \\
{[22]}\end{array}$ & $\begin{array}{l}\text { 1) споживча цінність продукту; } \\
\text { 2) формула прибутку; } \\
\text { 3) ключові ресурси; } \\
\text { 4) ключові процеси. }\end{array}$ \\
\hline $\begin{array}{c}\text { Кузьміна Н.В. } \\
{[13, \text { с.397] }}\end{array}$ & $\begin{array}{l}\text { 1) стратегія; } \\
\text { 2) економіка; } \\
\text { 3) підприємництво; } \\
\text { 4) фінанси; } \\
\text { 5) операції; } \\
\text { 6) маркетинг; } \\
\text { 7) конкурентні стратегї; } \\
\text { 8) стратегї стійкого росту тощо. }\end{array}$ \\
\hline $\begin{array}{c}\text { Сачинська Л.В. } \\
{[\underline{10}, \text { с. } 174]}\end{array}$ & $\begin{array}{l}\text { 1) цінність (товари, продукти, послуги), що пропонує компанія для своїх клієнтів; } \\
\text { 2) система клієнтів і постачальників, ланцюжки створення цінності; } \\
\text { 3) активи підприємства; } \\
\text { 4) фінансова модель формування доходів, витрат і фінансових результатів підприємства. }\end{array}$ \\
\hline $\begin{array}{l}\text { Чесбро Г. } \\
{[17, \text { с. } 80]}\end{array}$ & $\begin{array}{l}\text { 1) ціннісна пропозиція; } \\
\text { 2) формула прибутку (джерела та обсяги доходів, структуру витрат, маржинальний } \\
\text { прибуток, оборотність ресурсів); } \\
\text { 3) ключові матеріальні і нематеріальні активи; } \\
\text { 4) ключові процеси. }\end{array}$ \\
\hline $\begin{array}{l}\text { Нехода Е.В., } \\
\text { Редчикова Н.А., } \\
\text { Тюленева Н.А. } \\
\text { [23] }\end{array}$ & $\begin{array}{l}\text { 1) наявність входів - ресурсів, які компанія використовує для цілей виробництва продукції } \\
\text { / надання послуг (створення вартості, споживчої цінності); } \\
\text { 2) стратегія і процеси перетворення ресурсів щодо створення вартості, споживчої цінності; } \\
\text { 3) наявність виходів - результатів діяльності компанії (доходи, прибуток, створення }\end{array}$ \\
\hline
\end{tabular}




\begin{tabular}{|c|c|}
\hline & споживчої цінності). \\
\hline $\begin{array}{c}\text { Стрекалова Н.Д. } \\
\text { [24] }\end{array}$ & $\begin{array}{ll}\text { 1. } & \text { Функції і цілі бізнесу. } \\
\text { 2. Ціннісні пропозиції. } \\
\text { 3. Ринок. } \\
\text { 4. Процесор: ланцюжок створення цінності; ключові ресурси і обладнання; каталізатор; } \\
\text { людські ресурси. } \\
\text { 5. Конкурентна стратегія. } \\
\text { 6. Мережа бізнесу. } \\
\text { 7. } \\
\text { Економічна модель } \\
\end{array}$ \\
\hline $\begin{array}{c}\text { Остервальдер А., } \\
\text { Піньє I. [25] }\end{array}$ & $\begin{array}{l}\text { 1) споживчий сегмент; } \\
\text { 2) ціннісна пропозиція або продукт; } \\
\text { 3) } \\
\text { 4анали збуту; } \\
\text { 5) взамовідносини з клієнтами; } \\
\text { 6) потоки надходження доходів; } \\
\text { 7) ключові ресурси; } \\
\text { 8) } \\
\text { слючові види діяльності; } \\
\text { 9) структу партнери; } \\
\text { стратрат. }\end{array}$ \\
\hline
\end{tabular}

\section{Складено автором}

Диференційовані підходи вчених до визначення компонентів бізнес-моделі підтверджують унікальність моделей залежно від обраного об'єкта дослідження та підходу, якого дотримуються науковці. Вагомий доробок у даному напрямку здійснили Остервальдер А., Піньє I. [25, с. 14] представивши схематично бізнес-модель у вигляді дев'яти блоків - ключових елементів бізнесу, що включає механізм створення, збереження та підвищення вартості підприємства.

\begin{tabular}{|c|c|c|c|c|c|c|c|c|}
\hline 8 & $\begin{array}{l}\text { Ключові } \\
\text { партнери }\end{array}$ & 7 & $\begin{array}{l}\text { Ключові } \\
\text { види } \\
\text { діяльності }\end{array}$ & $\begin{array}{l}\text { Цінність } \\
\text { пропозиції/ } \\
\text { продукт }\end{array}$ & 4 & $\begin{array}{c}\text { Взаємовідносини } 3 \\
\text { кліснтами }\end{array}$ & 1 & Споживачі \\
\hline \multirow{3}{*}{\multicolumn{2}{|c|}{$\begin{array}{c}\text { Хто є ключовими } \\
\text { партнерами, } \\
\text { постачальниками? Які } \\
\text { ресурси отримуємо? } \\
\text { Чим займаються } \\
\text { партнери? }\end{array}$}} & \multicolumn{2}{|c|}{$\begin{array}{c}\text { Які види } \\
\text { діяльності здатні } \\
\text { створювати } \\
\text { канали збуту і } \\
\text { збільшувати } \\
\text { доходи бізнесу? }\end{array}$} & \multirow{3}{*}{$\begin{array}{c}\text { Яку цінність ми } \\
\text { представляємо для } \\
\text { клієнта? } \\
\text { Які проблеми } \\
\text { клієнта ми } \\
\text { допомагаємо } \\
\text { вирішити? } \\
\text { Які продукти ми } \\
\text { пропонуємо } \\
\text { кожному сегменту } \\
\text { клієнтів? } \\
\text { Яку потребу клієнтів } \\
\text { задовольняємо? }\end{array}$} & \multicolumn{2}{|r|}{$\begin{array}{c}\text { Які відносини очікує } \\
\text { окремий клієнтський } \\
\text { сегмент? Які наявні } \\
\text { взаємовідносини з } \\
\text { клієнтами, їх інтегрованість } \\
\text { в бізнес-модель і вартість? }\end{array}$} & \multirow{3}{*}{\multicolumn{2}{|c|}{$\begin{array}{c}\text { Хто наш клієнт? } \\
\text { Для кого } \\
\text { створюємо } \\
\text { ціннісну } \\
\text { пропозицію? Який } \\
\text { сегмент } \\
\text { споживачів } \\
\text { найбільш } \\
\text { важливий для нас? }\end{array}$}} \\
\hline & & 6 & $\begin{array}{l}\text { Ключові } \\
\text { ресурси }\end{array}$ & & 3 & Канали збуту & & \\
\hline & & & $\begin{array}{c}\text { Які засоби } \\
\text { необхідні для } \\
\text { пропозиції, } \\
\text { надання та } \\
\text { реалізації всіх } \\
\text { лементів бізнес- } \\
\text { моделі? Які } \\
\text { ключові ресурси } \\
\text { ожуть збільшити } \\
\text { дохід? }\end{array}$ & & & $\begin{array}{l}\text { Яким чином отримують } \\
\text { клієнти інформацію про } \\
\text { iннісні пропозиції? Як це } \\
\text { роблять конкуренти? Які } \\
\text { анали збуту є економічно } \\
\text { игідними? Наскільки різні } \\
\text { анали збуту інтегровані? } \\
\text { Якими каналами } \\
\text { користуються клієнти? }\end{array}$ & & \\
\hline 9 & \multicolumn{4}{|l|}{ Витрати } & \multicolumn{4}{|c|}{\begin{tabular}{l|l}
5 & Доходи \\
\end{tabular}} \\
\hline \multicolumn{5}{|c|}{$\begin{array}{l}\text { Які ресурси найдорожчі? Які витрати найбільші? Які напрямки } \\
\text { діяльності найбільш витратні? }\end{array}$} & \multicolumn{4}{|c|}{$\begin{array}{c}\text { Які джерела доходів отримує бізнес? Скільки } \\
\text { платять клієнти? Як вони платять? Як би хотіли } \\
\text { платити? Яка доля окремого грошового потоку в } \\
\text { загальних доходах бізнесу? }\end{array}$} \\
\hline
\end{tabular}

Рисунок 4 - Канва бізнес-моделі Остервальдера А. і Пінье I. [25]

Канва бізнес-моделі Остервальдера А. і Піньє І. набула широкого поширення у міжнародній практиці бізнесу, в економічні теорії Кукушкін С.Н. [26] запропонував 
власне бачення формування дзеркальної бізнес-моделі Остервальдера А., Піньє І. для університетів, акцентуючи увагу, що ключовим ресурсом, споживачем і ціннісною пропозицією $є$ майбутній спеціаліст, а університет здійснюючи науково-дослідну діяльність є імпульсом розвитку, створюючи нові знання.

Канва бізнес-моделі визначає лише блоки, які потребують змістовного наповнення відповідно до об'єкта дослідження з урахуванням реалій та діяльності суб'єкта, тому враховуючи дію зовнішнього та внутрішнього середовища вітчизняних університетів запропоновано іï змістовне наповнення (рис. 5).

Спожсивчий сегмент. Заклади вищої освіти орієнтуються на різні сегменти споживачів, залежно від їх типу: класичний, технічний, галузевий (педагогічний, гуманітарний, медичний, економічний, юридичний, аграрний, мистецький тощо). Рівень інноваційності, кадровий потенціал, матеріально-технічна база визначають частку споживачів освітніх послуг. Когортою споживачів будь-якого ЗВО є випускники шкіл, як потенційні абітурієнти, випускники бакалавріату та магістратури, які можуть навчатися на освітніх програмах магістерського рівня, іміджевих програмах, відвідувати різноманітні тренінги, курси, програми тощо. Окрема категорія споживачів - доросле населення, фізичні особи, які продовжують навчання протягом життя підвищуючи свій рівень професійних знань у певній галузі, відвідуючи курси, тренінги, бізнес-програми тощо. Замовниками освітніх послуг та наукових досліджень можуть бути представники органів місцевого самоврядування, керівники підприємств, установ, організацій. При взаємодії із ними заклади вищої освіти використовують клієнтоорієнтований підхід розробляючи освітні програми, бізнес-курси, сертифікатні програми, тренінги тощо під замовлення клієнта відповідно до їх потреби, враховуючи всі вподобання у змісті програми.

Ціннісна пропозиція або продукт. Університети повинні визначити чому клієнти отримують ціннісні пропозиції, наприклад, освітні послуги саме в цьому закладі вищої освіти, а не іншому, враховуючи такі критерії, як новизна, надійність, ефективність, якість, вартість, престижність тощо. Наразі університети поступово змінюють підхід до формування переліку освітніх послуг, все більше зміщуючи фокус на інтерес клієнтів, що стимулює їх створювати нові, інноваційні, якісні продукти при взаємодії із стейкголдерами. Університети, в якості продукту пропонують на ринок освітніх послуг: освітньо-професійні, освітньо-наукові, іміджеві, бізнес програми, сертифікатні програми, тренінги, курси професійного вдосконалення, науково-дослідні розробки тощо, орієнтуючись на певний сегмент споживачів.

Канали збуту показують яким чином отримують клієнти інформацію про ціннісні пропозиції, так університети просувають свої продукти через соціальні мережі (Facebook, Instagram, Telegram тощо), офіційний сайт університету, дні відкритих дверей, профорієнтаційні заходи, рекламу тощо. Проте, найбільш дієвим каналом збуту залишаються особисті взаємовідносини з клієнтами, партнерами і результати співпраці між ними.

Взаємовідносини з клієнтами. На рівні університету взаємовідносини 3 клієнтами реалізуються на договірній основі, і підтримуються як керівництвом 3ВО, так і відповідними службами, відділами, що відповідають за встановлення, налагодження та розвиток партнерських відносин. 


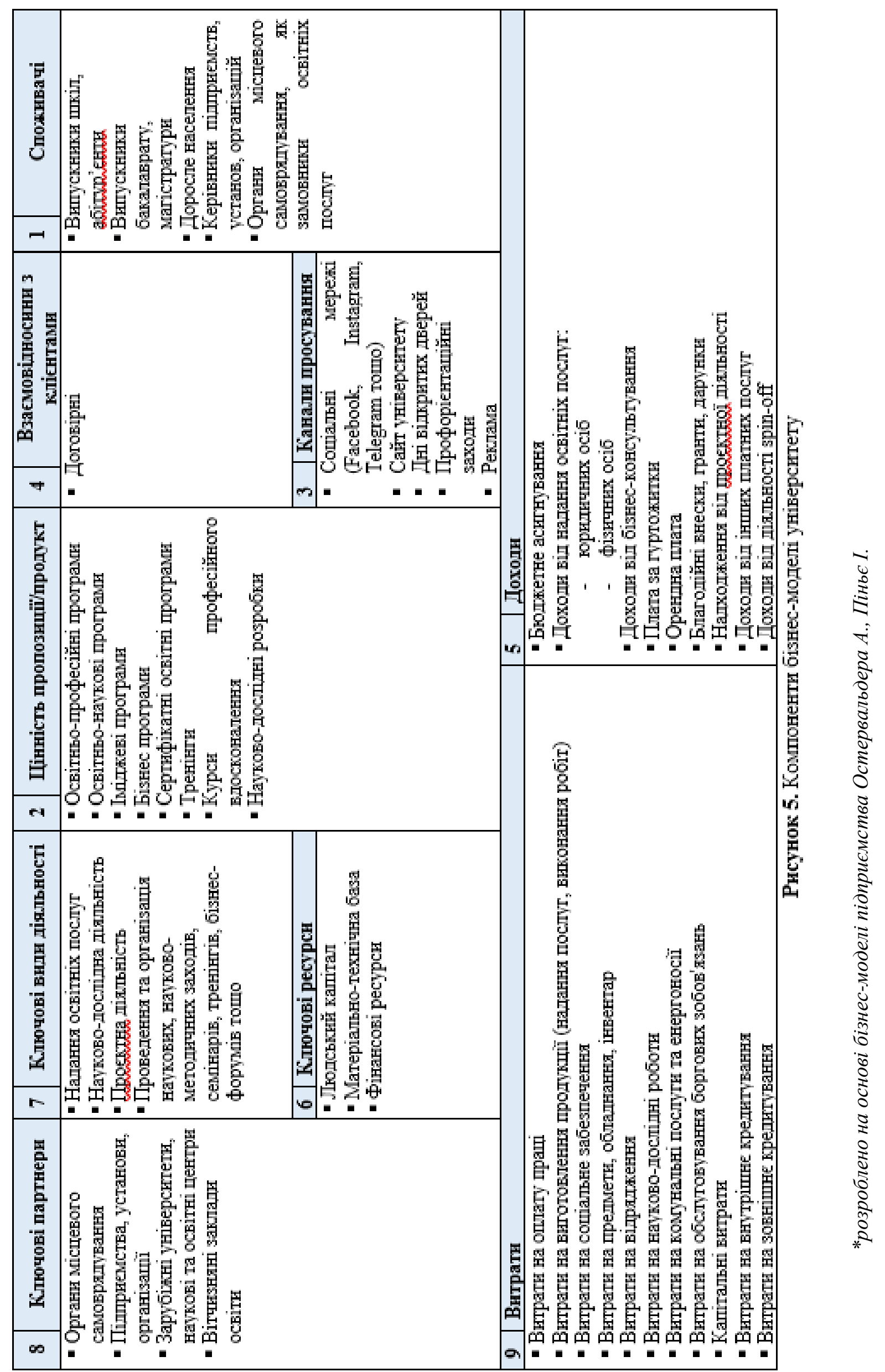


Доходи університету, що виникають завдяки успішним ціннісним пропозиціям клієнтам, за які вони готові плати. В діяльності вітчизняних університетів наразі основне джерело доходів залишається бюджетні асигнування, розмір яких залежав від контингенту студентів, починаючи 32020 року на обсяг бюджетних асигнувань впливає масштабність університету, контингент студентів, регіональний коефіцієнт, позиції у міжнародних рейтингах, обсяг коштів на дослідження, які університет залучає 3 позабюджетних джерел, працевлаштування випускників. Вагому частку доходів університету формують доходи від надання освітніх послуг, частка яких у різних 3ВО розподілена по різному, так як включає плату за освітні послуги юридичних і фізичних осіб. Вартість освітніх програм диференціюється залежно від їх категорії, якісного рівня іiі реалізації, сегмента споживачів. Якщо 3ВО мають власні гуртожитки, то отримують плату за гуртожитки. Окремо можна виділити доходи отримані від благодійної діяльності, гранти, дарунки, проєктна діяльність тощо. Наразі 3ВО розвивають і диверсифікують платні послуги, які задовольняють потребу клієнтів щодо «Lifelong learning» (навчання протягом усього життя), що стає стабільним джерелом доходу. Проте, їх кількість і спектр диверсифікації залежить як від екзогенних, так і ендогенних чинників.

Ключові ресурси - засоби, що необхідні для пропозиції, надання та реалізації всіх елементів бізнес-моделі, а саме ключові ресурси за допомогою яких можна збільшити дохід. В університетах ключовими ресурсами, які створюють продукт $є$ людський капітал, в т. ч. інтелектуальний капітал і матеріально-технічна база закладу.

Ключові види діяльності, що створюють канали збуту і збільшують доходи. В університетах - це надання освітніх послуг, здійснення науково-дослідної діяльності, проєктної діяльності, організація та проведення наукових, науково-методичних заходів, семінарів, тренінгів, бізнес-форумів тощо. Проте, їх пріоритетність залежить від ряду чинників, які впливають як на попит, так і пропозицію зазначених послуг.

Ключові партнери. В університетах - це органи місцевого самоврядування, підприємства, установи, організації, зарубіжні університети, наукові та освітні центри, вітчизняні заклади освіти. Партнери можуть бути одночасно і клієнтами, замовниками освітньо-наукового продукту, саме в цьому випадку заклад має врахувати всі характеристики партнера і задовольнити його очікування.

Cтруктура витрат формується як результат взаємодії всіх елементів бізнесмоделі, проте в закладах вищої освіти найбільшу питому вагу в структурі витрат займають витрати на оплату праці, так як ключовим ресурсом є людський капітал. Іміджеві, бізнес-програми $є$ дорогими для клієнта, водночас затратними для університету, адже потребують залучення професіоналів, бізнес-тренерів, практиків, проте саме вони можуть задовольнити кінцевий інтерес клієнта, створивши якісний продукт. До інших складових витрат відносять: витрати на виготовлення продукції (надання послуг, виконання робіт), витрати на соціальне забезпечення, витрати на предмети, обладнання, інвентар, витрати на відрядження, витрати на науково-дослідні роботи, витрати на комунальні послуги та енергоносії, витрати на обслуговування боргових зобов'язань, капітальні витрати, витрати на внутрішнє кредитування та зовнішнє кредитування.

Висновки і перспективи подалыших досліджень. В результаті проведеного дослідження було систематизовано підходи до розуміння поняття «бізнес-модель», серед яких виокремлено стратегічний, клієнтоорієнтований, ціннісний, процесний, системний також підходи, що ототожнюють бізнес-модель як інструмент управління, 
механізм, визначають ії як когнітивну систему. Наведені бачення науковців, щодо компонентів бізнес-моделі підтверджує їі унікальність і практичну значимість.

Запропоноване власне бачення поняття «бізнес-модель університету» як концептуального інструменту, який базується на стратегічному баченні розвитку закладу вищої освіти, включає взаємопов'язаний набір компонентів створення ціннісної пропозиції для стейкголдерів та здатності університету генерувати доходи задля забезпечення фінансової стійкості. Визначено, що при розробці бізнес-моделі університету доцільно дотримуватися комплексного підходу до іiі формування, що поєднує стратегічний, ціннісний, клієнтоорієнтований, процесний і системний підходи.

На основі канви бізнес-моделі підприємства Остервальдера А., Піньє І. було запропоновано змістовне iї наповнення для університетів. Тому необхідність подальшого дослідження має здійснюватися в напрямку розробки і впровадження бізнес-моделей для вітчизняних університетів із урахуванням їх кластиризації.

\section{СПИСОК ВИКОРИСТАНИХ ДЖЕРЕЛ}

1. Остервальдер, А., Пинье, И. (2012). Построение бизнес-моделей: Настольная книга стратега и новатора. Альпина Паблишер.

2. Скриль, В. В. (2016). Бізнес-моделі підприємства: еволюція та класифікація. Науковий вісник Мукачівського державного університету. Серія: Економіка i суспільство.

3. Foss N.J., Saebi T. (2017). Fifteen years of research on business model innovation: How far have we come, and where should we go? Journal of Management, vol. 43, no. 1, pp. 200227. DOI: https://doi.org/10.1177/0149206316675927.

4. Чухрай, А. І. (2012). Онтологія поняття “бізнес-модель” підприємства.

5. Casadesus-Masanell, R., Ricart, J. E. (2010). From strategy to business models and onto tactics. Long range planning, 43 (2-3), 195-215.

6. Keen, P., Qureshi, S. (2006). Organizational Transformation through Business Models: A Framework for Business Model Design. System Sciences, HICSS'06. Proceedings of the 39th Annual Hawaii International Conference, V.8, P.206b-206b

7. Hamel G. 2000. Leading the Revolution. Plume: N.Y.

8. Сливотски, А. (2006). Миграция ценности. Что будет с вашим бизнесом послезавтра: пер. с англ. М.: Манн, Иванов и Фербер.

9. Zott, C., \& Amit, R. (2010). Business model design: an activity system perspective. Long range planning, 43(2-3), 216-226.

10. Сачинська, Л. В. (2015). Особливості формування бізнес-моделі підприємства. Економічні науки. Серія: Облік і фінанси, (12 (2)), 171-179.

11. Afuah, A. (2004). Business models: A strategic management approach. McGrawHill/Irwin.

12. Pohle, G., Chapman, M. (2006). IBM's global CEO report 2006: business model innovation matters. Strategy \& Leadership.

13. Кузьмина, Н. В. (2020). Особенности формирования бизнес-модели предприятия в условиях динамичной внешней среды. Национальные экономические системы в контексте формирования глобального экономического пространства, 397-399.

14. Климанов, Д. Е., Третьяк, О. А. (2014). Бизнес-модели: основные направления исследований и поиски содержательного фундамента концепции. Российский журнал менеджмента, 12(3).

15. Magretta, J. (2002). Why Business Models Matter. Harvard Business Review. 80(5), 8692. 
16. Нєнно, I. М. (2016). Щодо форм візуалізації бізнес-моделей. Вісник Донбаської державної машинобудівної академії, (3), 137-141.

17. Chesbrough, H., Rosenbloom, R. S. (2002). The role of the business model in capturing value from innovation: evidence from Xerox Corporation's technology spin- off companies. Industrial and corporate change, 11(3), 529-555.

18. Стрекалова, Н. Д. (2009). Концепция бизнес-модели: методология системного анализа. Известия Российского государственного педагогического университета им. АИ Герцена, (92).

19. Жайлауов, Е. Б., Белик, Е. Б., Денисов, И. В. (2019). Представление бизнес-модели как когнитивной системы. Вопросы инновационной экономики, 9(4), 1525-1534.

20. Закону України «Про вищу освіту». Редакція від 25.09.2020. URL: https://cutt.ly/2g06VnU

21. Чухрай, А. І. (2012). Онтологія поняття “бізнес-модель” підприємства.

22. Джонсон, М., Кристенсен, К., Кагерманн, Х. (2009). Обновление бизнес-модели. Harvard Business Review, 3, 63.

23. Нехода, Е. В., Редчикова, Н. А., Тюленева, Н. А. (2018). Бизнес-модели компаний: от прибыли к устойчивому развитию и созданию ценности. Управленец, 9(4).

24. Стрекалова, Н. Д. (2009). Бизнес-модель как полезная концепция стратегического управления. Проблемы современной экономики, 2, 133-138.

25. Osterwalder, A., Pigneur, Y. (2010). Business model generation: a handbook for visionaries, game changers, and challengers. John Wiley \& Sons.

26. Кукушкин, С. Н. (2018). Бизнес-модель организации в экономике знаний. Вестник Российского экономического университета им. ГВ Плеханова, (6 (102)).

\section{REFERENCES}

1. Osterval'der, A., Pin'e, I. (2012). Postroenie biznes-modelej: Nastol'naja kniga stratega i novatora. Al'pina Pablisher.

2. Skryl', V. V. (2016). Biznes-modeli pidpryiemstva: evoliutsiia ta klasyfikatsiia. Naukovyj visnyk Mukachivs'koho derzhavnoho universytetu. Seriia: Ekonomika i suspil'stvo.

3. Foss N.J., Saebi T. (2017). Fifteen years of research on business model innovation: How far have we come, and where should we go? Journal of Management, vol. 43, no. 1, pp. 200227. DOI: https://doi.org/10.1177/0149206316675927.

4. Chukhraj, A. I. (2012). Ontolohiia poniattia "biznes-model"' pidpryiemstva.

5. Casadesus-Masanell, R., Ricart, J. E. (2010). From strategy to business models and onto tactics. Long range planning, 43 (2-3), 195-215.

6. Keen, P., Qureshi, S. (2006). Organizational Transformation through Business Models: A Framework for Business Model Design. System Sciences, HICSS'06. Proceedings of the 39th Annual Hawaii International Conference, V.8, P.206b-206b

7. Hamel G. 2000. Leading the Revolution. Plume: N.Y.

8. Slivotski, A. (2006). Migracija cennosti. Chto budet s vashim biznesom poslezavtra: per. s angl. M.: Mann, Ivanov i Ferber.

9. Zott, C., Amit, R. (2010). Business model design: an activity system perspective. Long range planning, 43(2-3), 216-226.

10. Sachyns'ka, L. V. (2015). Osoblyvosti formuvannia biznes-modeli pidpryiemstva. Ekonomichni nauky. Ceriia: Oblik i finansy, (12 (2)), 171-179.

11. Afuah, A. (2004). Business models: A strategic management approach. McGrawHill/Irwin. 
12. Pohle, G., Chapman, M. (2006). IBM's global CEO report 2006: business model innovation matters. Strategy \& Leadership.

13. Kuz'mina, N. V. (2020). Osobennosti formirovanija biznes-modeli predprijatija v uslovijah dinamichnoj vneshnej sredy. Nacional'nye jekonomicheskie sistemy v kontekste formirovanija global'nogo jekonomicheskogo prostranstva, 397-399.

14. Klimanov, D. E., Tret'jak, O. A. (2014). Biznes-modeli: osnovnye napravlenija issledovanij i poiski soderzhatel'nogo fundamenta koncepcii. Rossijskij zhurnal menedzhmenta, 12(3).

15. Magretta, J. (2002). Why Business Models Matter. Harvard Business Review. 80(5), 8692.

16. Nienno, I. M. (2016). Schodo form vizualizatsii biznes-modelej. Visnyk Donbas'koi derzhavnoi mashynobudivnoi akademii, (3), 137-141.

17. Chesbrough, H., Rosenbloom, R. S. (2002). The role of the business model in capturing value from innovation: evidence from Xerox Corporation's technology spin- off companies. Industrial and corporate change, 11(3), 529-555.

18. Strekalova, N. D. (2009). Koncepcija biznes-modeli: metodologija sistemnogo analiza. Izvestija Rossijskogo gosudarstvennogo pedagogicheskogo universiteta im. AI Gercena, (92).

19. Zhajlauov, E. B., Belik, E. B., Denisov, I. V. (2019). Predstavlenie biznes-modeli kak kognitivnoj sistemy. Voprosy innovacionnoj jekonomiki, 9(4), 1525-1534.

20. Zakonu Ukrainy «Pro vyschu osvitu». Redaktsiia vid 25.09.2020. URL: https://cutt.ly/2g06VnU

21. Chukhraj, A. I. (2012). Ontolohiia poniattia "biznes-model"' pidpryiemstva.

22. Dzhonson, M., Kristensen, K., \& Kagermann, H. (2009). Obnovlenie biznes-modeli. Harvard Business Review, 3, 63.

23. Nehoda, E. V., Redchikova, N. A., Tjuleneva, N. A. (2018). Biznes-modeli kompanij: ot pribyli k ustojchivomu razvitiju i sozdaniju cennosti. Upravlenec, 9(4).

24. Strekalova, N. D. (2009). Biznes-model' kak poleznaja koncepcija strategicheskogo upravlenija. Problemy sovremennoj jekonomiki, 2, 133-138.

25. Osterwalder, A., Pigneur, Y. (2010). Business model generation: a handbook for visionaries, game changers, and challengers. John Wiley \& Sons.

26. Kukushkin, S. N. (2018). Biznes-model' organizacii v jekonomike znanij. Vestnik Rossijskogo jekonomicheskogo universiteta im. GV Plehanova, (6 (102)).

Юрчишена Л.В., кандидат экономических наук, доцент, доцент кафедры финансов и банковского дела, Донецкого национального университета имени Василия Стуса, ORCID: 0000-0002-5904-0758

l.yurchishena@donnu.edu.ua

ОПРЕДЕЛЕНИЕ БИЗНЕС-МОДЕЛИ УНИВЕРСИТЕТА НА ОСНОВЕ СИНТЕЗА ПОДХОДОВ К БИЗНЕС-МОДЕЛИ ПРЕДПРИЯТИЯ

В статье исследованы и структурировано генезис подходов отечественных $и$ иностранных ученых $\kappa$ понятию «бизнес-модель», в результате выделены стратегический, клиентоориентированный, ценностный, процессный, системный подход, а также подходы, которые отождествляют бизнес-модель как инструмент управления, механизм, определяют ее как когнитивную систему. Исследуются подходь ученых $\kappa$ наполненности бизнес-модели компонентами, что подтверждает ее уникальность и возможность использования в различных отраслях.

Определено, что при разработке бизнес-модели университета целесообразно придерживаться комплексного подхода, сочетающего стратегический, иенностный, 
клиентоориентированный, процессный и системный подходы. Приведено понимания понятия бизнес-модель университета как кониептуального инструмента, который базируется на стратегическом видении развития учреждения высшего образования, включая взаимосвязанный набор компонентов создания иенностного предложения для стейкголдеров и способности университета генерировать доходы для обеспечения финансовой устойчивости. Осуществлено содержательное наполнение составляющих бизнес-модели Остервальдера А., Пинье И. для отечественных университетов.

Ключевые слова: бизнес-модель, бизнес-модель университета, ценностное предложение, компоненты бизнес-модели, канва бизнес-модели.

L. Yurchyshena, $\mathrm{PhD}$ in Economics, Associate Professor, Department of Finance and Banking, Vasyl' Stus Donetsk National University

\section{DEFINING THE BUSINESS MODEL OF THE UNIVERSITY BASED ON A SYNTHESIS OF APPROACHES TO THE BUSINESS MODEL OF THE ENTERPRISE}

The article investigates and structures the genesis of approaches of domestic and foreign scientists to the concept of "business model", as a result the strategic, customer-oriented, value, process, system approach, as well as approaches that identify the business model as a management tool, mechanism, define it. as a cognitive system. The approaches of scientists to the filling of the business model with components are studied, which proves its uniqueness and possibility of use in different fields. It is determined that when developing a business model of the university it is advisable to follow a comprehensive approach that combines strategic, value, customer-oriented, process and system approaches. The understanding of the university business model as a conceptual tool based on a strategic vision of higher education development, including an interconnected set of components of creating a value proposition for stakeholders and the university's ability to generate revenue to ensure financial stability. The components of the business model of Osterwalder A. and Pigneur Y. for domestic universities have been filled in meaningfully.

Keywords: business model, university business model, value proposition, business model components, business model outline. 